\title{
Organic Agricultural Products: A Comparative Study of India with Other Economies
}

\author{
Sujaya H. ${ }^{1}$, Meghana Salins ${ }^{1} \&$ P. S. Aithal ${ }^{2}$ \\ ${ }^{1}$ Research Scholar, College of Management \& Commerce, Srinivas University, Mangalore, \\ India \\ ${ }^{2}$ College of Management \& Commerce, Srinivas University, Mangalore, India \\ Email: sujayaloknath@gmail.com
}

Type of the Paper: Research Case Study.

Type of Review: Peer Reviewed.

Indexed In: OpenAIRE.

DOI: http://doi.org/10.5281/zenodo.2530409.

Google Scholar Citation: IJCSBE

\section{How to Cite this Paper:}

Sujaya, H., Salins, Meghana., \& Aithal, P. S. (2018). Organic Agricultural Products: A Comparative Study of India with Other Economies. International Journal of Case Studies in Business, IT and Education (IJCSBE), 2(2), 86-97.

DOI: http://doi.org/10.5281/zenodo.2530409.

International Journal of Case Studies in Business, IT and Education (IJCSBE)

A Refereed International Journal of Srinivas University, India.

(c) With Authors.

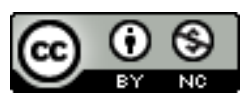

This work is licensed under a Creative Commons Attribution-Non Commercial 4.0 International License subject to proper citation to the publication source of the work.

Disclaimer: The scholarly papers as reviewed and published by the Srinivas Publications (S.P.), India are the views and opinions of their respective authors and are not the views or opinions of the S.P. The S.P. disclaims of any harm or loss caused due to the published content to any party. 


\title{
Organic Agricultural Products: A Comparative Study of India with Other Economies
}

\author{
Sujaya H. ${ }^{1}$, Meghana Salins ${ }^{1}$ \& P. S. Aithal ${ }^{2}$ \\ ${ }^{1}$ Research Scholar, College of Management \& Commerce, Srinivas University, Mangalore, \\ India \\ ${ }^{2}$ College of Management \& Commerce, Srinivas University, Mangalore, India \\ Email: sujayaloknath@gmail.com
}

\begin{abstract}
Organic agricultural products have a unique method of production which protects the environment and minimizes the erosion of soil and thereby reduces pollution by encouraging a balanced system of usage of organic standard for agriculture products in India and other economies. The main objective of this case study is to assess the factors that influence the utilization of the geographical area and export activities of organic products in the Asian continent including India. This case study highlights the issues related to organic farming and is developed by using secondary data to assess the factors that influence agricultural organic products. The secondary data were obtained from exhaustive literature reviews of journals and internet sources. The scope of the case study is limited to the organic products and land areas which are used for its cultivation. The analysis of secondary data reveals that along with the increase in production, there is also an increase in the different varieties of organic agricultural products. It is evident that organic farming has increased due to increased land usage for the cultivation in recent years in the Asian continent. From the study it is observed that the cumulative aggregate growth rate has increased from $6 \%$ to $29 \%$ during the year 2010-11 till 2015-16.
\end{abstract}

Keywords: Organic agricultural products, Wild harvest, Cultivated area, Cumulative aggregate growth.

\section{INTRODUCTION :}

India is one of the fastest growing economies in the world. Agriculture is the primary occupation of Indian from ancient time till date though the number of people working in the agricultural field has been decreased.It has been decreased from 89 percentages to 55 percentages due to industrialization and tertiary sector development. Still, Indian agriculture is playing a vital role in supplying its products to the domestic as well as international consumers. The advent of the green revolution has made remarkable progress in the field of agriculture. Further, the tremendous progress of Indian agriculture has been happened with the liberalization, privatization, and globalization.Though organic agricultural production process is rooted in India from early stages of agriculture, it has shown its revolutionary changes in recent times. Organic farming is a holistic production and enhances ecosystem health, biological cycles, biodiversity, and soil biological activities.

The fast-growing population and the development of the industrial sector has a great impact on the production methods of improvement in the yielding of crops. The studies have revealed about the higher usage of chemical and fertilizers for yielding the production of food products. The present consumers are aware of the chemical and polluted food products available in the market, which thereby make them to turn towards the organic food products. These organic foodstuffs are totally chemical free without the usage of pesticides and insecticides and other related chemicals which prove harmful to health and the environment. There is a paradigm shift in the export of the major organic products from India to USA and also to Europe in the modern days. There is also highly utilization of cultivated lands for the purpose of developing organic farming and its products. 
Nowadays, the usage and growth of organic products have rapidly increased due to consumer's attitude towards health consciousness and pollution control environment. The price factor of the organic product plays a crucial role by affecting the consumer belief and attitude negatively [1-2]. But some studies reveal that consumers are tolerant to the prices of organic foods such as one of the American food retailers who supplies organic food products give various reasons about how people prefer these food products due to avoidance of the effects of harmful pesticides and insecticides and for healthy eating and living [3-5]. Studies reveal about the norms which are subjective based on the consumer`s attitude and intention to buy organic food products.

\section{OBJECTIVES OF THE STUDY :}

This study is limited to organic agricultural products and itscomparison with India and other economies. The main objectives are:

(1) To explore the organic agricultural products at an international level.

(2) To investigate the trends of organic agricultural products usage in India.

(3) To analyze the export of organic agricultural products from India.

(4) To compare the production of organic agricultural products in other countries.

(5) To predict future demands and their fulfilment strategies in India.

\section{RESEARCH METHODOLOGY :}

This case study is developed on the basis of secondary data. Published sources are taken into consideration for the analysis of the data. The information about the organic agricultural products and its farming practices in India and abroad is collected from the published sources. The main sources are international trade Centre, Research Institute of Organic Agriculture, The International Federation of Organic Agriculture Movements, The Agricultural and Processed Food Products Export Development Authority, and The World of Organic Agriculture Statistics and Emerging Trend. In this case study the growth rate of an organic farming area, export of the products internationally and also cultivated and world harvest areas are taken into consideration and analyzed.

\section{CONCEPTUAL FRAMEWORK OF THESTUDY :}

People are far more considered about their health in recent days and they often take precautionary measures to control their health. People often to keep them safe from sickness intake various medicines and antibiotics which particularly make them still unhealthy. The additional dose of these heavy medications eventually reduces their immune system and reduce their resistance power by overall pushing them to deadly diseases. The organic food producers and farmers do not use such antibiotics in their process and the organics stuff are prepared in a natural way without the usage of chemicals which do not show any effect to the human body. Perception and consumer behaviour are likely to affect the purchasing intention of the consumers towards organic agricultural products in both developing and developed economies. Consumers buying behaviour and health consciousness in developed economies are quite higher compared to developing economies. The study also reveals that country like India has low health consciousness towards organic product where the sales are still in the introduction level. Consumer's consciousness towards health and the people`s concern about organic products started to grow with the awareness of safety and security for life and health [6].

Prior research in this field has examined the health condition of people who have consumed organic agricultural productsin France and Canada [7]. Though the findings of such research highlight the ignorance of people about health aspects [8]in connection with organic agricultural products, several other research studies show theopposite result [9]. Since organic products are found to improve the health conditions of the people, there was an increased demand for organic products [10-11]. Though it is found that many people fail to buy organic agricultural products though they are health conscious, due to the reason of the high price of suchproducts[12].

Consumers approach may be positive based on using organic products for consumption which tend to a healthier and a safer product compared to conventional product. The consumers consider that the organic products should be produced at domestic level or imported from other countries which in term gives detailed information about the producing country and the percentage of freshness and how these products are an added advantage for the country and for the consumer's health [13-15]. 


\section{International Journal of Case Studies in Business, IT and Education SRINIVAS (IJCSBE), ISSN: 2581-6942, Vol. 2, No. 2, December 2018.

\section{RESULTS AND ANALYSIS :}

The organic agriculture is defined as "A production system that sustains the health of soils, ecosystems, and people. It depends on ecological processes, biodiversity and cycles adapted to local conditions, rather the use of inputs with adverse effects". Organic agricultural products are highly sold in US economy in the year 2017, followed by European countries like Germany and France. It was reported that nearly 90-billion-dollars world organic agricultural products are sold on USA in the year 2016. But in the consumption matter of organic agricultural products, Switzerland stands number one followed by Denmark and Sweden. Worldwide the utilization of land for organic agricultural products cultivation has been increased from 11 million hectares in 2015. But the country which has utilized the highest area for the cultivation of organic products in Australia, Argentina, and China respectively. The report indicates that utilization of land area for cultivation is 27.1 million hectares, 3 million hectares and 2.4 million hectares by Australia, Argentina, and China respectively.

India is one of the fastest growing in the field of agricultural aspects and in modern times the concentration on agricultural organic products are increasing a lot. There are 835,000 certified agricultural organic product producers in India. Out of total contribution in the field of agricultural organic product India's contribution ix 2.7 million according to the world of organic agricultural report 2018. The report also indicates that among the certified organic cultivation, India utilized only 1.5 million hectares of land out of 57.8 million hectares land for the purpose of production of agricultural organic products. On the basis of the data collected by International Trade Centre, Research Institute of organic agriculture, and the state of sustainability initiatives from 178 countries has shown that organic agricultural areas used for the cultivation of organic agricultural products have been increased along with the increase in the product's level. The report also indicates that along with the increase in the products there is also an increase in the different varieties of organic agricultural products.

Table 1:Asian continent and organic agricultural land development for the year 2002-2017

\begin{tabular}{|l|l|}
\hline Year & Million hectares \\
\hline 2000 & 0.06 \\
\hline 2001 & 0.42 \\
\hline 2002 & 0.43 \\
\hline 2003 & 0.49 \\
\hline 2004 & 3.78 \\
\hline 2005 & 2.68 \\
\hline 2006 & 3.00 \\
\hline 2007 & 2.9 \\
\hline 2008 & 3.36 \\
\hline 2009 & 3.58 \\
\hline 2010 & 2.46 \\
\hline 2011 & 3.69 \\
\hline 2012 & 3.22 \\
\hline 2013 & 3.41 \\
\hline 2014 & 3.57 \\
\hline 2015 & 3.97 \\
\hline
\end{tabular}

Source: FiBL-IFOAM-SOEL 2002-2017.

Asia though has a high potential and untapped market the demand for the organic products are drastically less when it is compared with the western world. The table 1 indicates that 0.49 million hectares of the land was utilized for the organic farming in Asian continent in the year 2003 which has come down in the year 2015 by utilizing 3.97 million hectares of land. But the total areas utilized for cultivation was very poor in Asia in the year 2000 which was improved a lot by the year 2015 from 0.06 million hectares to 3.97 million hectares. Thus, this is evidence that organic farming has increased undertaking land for the cultivation in recent times in the Asian continent. 


\section{ORGANIC PRODUCT CULTIVATION LAND AREA IN INDIA:}

Table 2:India`s organic cultivated land area

\begin{tabular}{|l|l|l|}
\hline \multicolumn{1}{|c|}{ Year } & Cultivated area in million hectares & Wild harvest area in million hectares \\
\hline $2010-11$ & 0.78 & 3.65 \\
\hline $2011-12$ & 1.00 & 4.55 \\
\hline $2012-13$ & 1.1 & 4.12 \\
\hline $2013-14$ & 0.72 & 4.00 \\
\hline $2014-15$ & 1.20 & 3.70 \\
\hline $2015-16$ & 1.49 & 4.22 \\
\hline
\end{tabular}

Source: APEDAAnnual Reports

From the table 2, it is very clear that India's organic cultivated area is 0.78 in the year 2010-11 which has raised to the level of 1.49 in the year 2015-16 which is an evidence that what ways the cultivated area for the organic farming is increasing in India. That means from 2010 till 2016 the cultivated land has been increased to 0.71 million hectares. This shows that in India organic farming is gaining its significance. In case of wild harvest area, it has increased from 3.65 million hectares to 4.22 million hectares from 2010-11 to 2015-16. That means from 2010 till 2016 the wild harvest land has been increased to 0.47 million hectares. It is clear from the table that the wild harvest area growth rate has been increased much higher than cultivated area. The cumulative aggregate growth rate has increased from $6 \%$ to $29 \%$ during the year 2010-11 till 2015-16.

\section{Indian export of organic farming products :}

Due to the demand for organic agricultural products are rising in the recent days there is a huge demand for the product internationally. This has led to higher export of organic products on the international level. Though India produces organic products it also exports it on the international level. This is mainly because advanced nations are highly aware of the positive results of organic farming and its product usage. The highest demand comes for Indian organic products are from the USA and Europe. The major products which are exported to the western world from India are organic basmati rice, spice, and herbs.

Table 3: Export of Indian organic farming products

\begin{tabular}{|l|l|}
\hline Year & Export in INR crore rupees \\
\hline $2010-11$ & 699 \\
\hline $2011-12$ & 1866 \\
\hline $2012-13$ & 2107 \\
\hline $2013-14$ & 2428 \\
\hline $2014-15$ & 2099 \\
\hline $2015-16$ & 1937 \\
\hline
\end{tabular}

Source: APEDA Annual Reports

Table 3 reveals the value of the export of organically farmed products are 699 crore rupees in the year 2010-11 has been increased to the level of 2428 crore rupees in the year 2013-14. The compound growth rate has been increased from $15 \%$ to $65 \%$ which shows India has a great market in the outer country than within the country.

\section{ORGANIC MARKET GROWTH FROM GLOBAL PERSPECTIVE :}

\subsection{Global Organic Market Growth:}

In order to do the production of organic product different organic techniques are been used by the producers. This organic farming is one of the best techniques for better environmental practices whereby natural resources can be preserved, animal welfare and production by use of natural substances can be maintained. Organic farming is practiced over by almost 162 countries.The countries such as North America dominates the global market with 33\% of its share and revenue. Europe has also has shifted its lifestyle toward usage of organic food products and has made more convenient to its consumers the product availability too. One of the leading countries with highest organic practices such as Germany is dominating the global market with its highest share followed by 
France, Spain, Russia, and Italy have a fast growth in organic food production. The Asian markets import major organic products from developed economies of North America and Europe.

In the Asia Pacific, the developed economies such as Japan, Australia, NewZealand, Singapore, Hongkong etc. are the major market for organic products. Developing countries like India and China have also set foot in the global level due to an increase in demand for organic products because ofconsumers organic purchase intentions.

According to an Ecovia Intelligence and FiBL survey, the data on the organic retail sale of food and beverages showed a CAGR $10.4 \%$ from 2000 to 2016 with the global sale has increased to US\$90 billion in 2016 from US\$17.9

Table 4: Organic market growth from a global prospective billion in 2000. It is further projected to record a growth of over CAGR 16\% during 2017.

\begin{tabular}{|l|l|}
\hline Year & $\begin{array}{l}\text { Organic market growth from global } \\
\text { perspective (in US\$ billion): }\end{array}$ \\
\hline 2011 & 59.4 \\
\hline 2012 & 65 \\
\hline 2013 & 71.5 \\
\hline 2015 & 79 \\
\hline 2016 & 88.1 \\
\hline
\end{tabular}

Source: The World of Organic Agriculture Statistics and Emerging Trend 2018, FiBL and IFOAM Organics International.

The top consumer of organic products for 2016 was the US (EUR38.9 billion sales), followed by Germany (EUR9.7 billion sales) and France (EUR6.7 billion sales). Globally, organic farming is practiced in 178 countries, but the largest single market was the US (47\%) followed by the European Union (EUR30.7 billion, 37\%) and China (EUR5.9 billion, 6\%). The highest growth (22\%) was registered in France and Ireland followed by Denmark and Norway with 20\% growth.

Table 5: The World of Organic Agriculture Statistics and Emerging Trend

\begin{tabular}{|l|l|l|l|l|}
\hline S. No. & Country & $\begin{array}{l}\text { Retail sales 2015 (EUR } \\
\text { Million) }\end{array}$ & $\begin{array}{l}\text { Retail sales 2016 } \\
\text { (EUR Million) }\end{array}$ \\
\hline 1 & USA & 35782 & 38938 \\
\hline 2 & Germany & 8620 & 9478 \\
\hline 3 & France & 5534 & 6736 \\
\hline 4 & China & 4712 & 5900 \\
\hline 5 & Canada & 2757 & 3002 \\
\hline 6 & Italy & 2317 & 2466 \\
\hline 7 & UK & 2604 & 2460 \\
\hline 8 & Switzerland & 2175 & 2298 \\
\hline 9 & Sweden & 1726 & 1944 \\
\hline 10 & India & 1036 & 1147 \\
\hline
\end{tabular}

Source: The World of Organic Agriculture Statistics and Emerging Trend 2018, FiBL and IFOAM Organics International.

Switzerland and Denmark have the highest per capita consumption. The organic market share has been maximum in (9.7\%), Luxemburg (8.6\%) and Switzerland (8.4\%) respectively. Due to the higher demand for organic products, the price of the products also increased. So, the international organic product producers are mainly concentrated towards reducing the price of the organic product on par with inorganic products. Moreover, as the demand for organic food products increases, product innovations and economies of scale would result in reducing the cost of production, further driving consumption of organic foods. 


\subsection{Comparative studyof the production of organic agricultural products in India with Other Countries:}

India being a developing country deals with the study of organic food products in comparison with other countries. The countries like North America and Europe has a $96 \%$ of revenue in the global level. The countries in the top list of organic food products are USA, France, Germany, Australia, Argentina with the large land area are behind the list of the organic market due to the variation in the pattern of productivity and consumption. But a country like India with 21 agro-ecological Zone has an added advantage of overproduction of various agriculture crops due to its different climatic nature and soil patterns and has a good market share of about 0.4 million with China at 0.1 million.

Table 6: Top 10 countries with the largest number of producers in the production of organic agriculture products (2016).

\begin{tabular}{|l|l|l|}
\hline S. No. & Country & Total number of producers \\
\hline 1 & India & 835000 \\
\hline 2 & Uganda & 210354 \\
\hline 3 & Mexico & 210000 \\
\hline 4 & Ethiopia & 203602 \\
\hline 5 & Philippines & 165994 \\
\hline 6 & Tanzania & 148610 \\
\hline 7 & Peru & 91771 \\
\hline 8 & Turkey & 67879 \\
\hline 9 & Italy & 64210 \\
\hline 10 & Paraguay & 58258 \\
\hline
\end{tabular}

Source: The world of Organic Agriculture Statistics and emerging trend 2018, FIBL and IFOAMOrganic International.

India is one of the leading organic producers in the globallevel with around a share of 8,35,000 farmers with Uganda in the second place with 2,10,354 farmers and Mexico with 2,10,000 farmers producing organic products. In Asian, African and Latin America there are almost $84 \%$ producers of organic products with Paraguay among the least in the top 10 countries. India also very active in the export of organic products such as spices, wheat, rice, pulses, fruits and vegetables. Countries such as Europe, UK, Germany, France, Italy, Canada, Africa, Middle East,Asian countries etc.

\section{SWOC ANALYSIS OF AGRICULTURAL ORGANIC PRODUCTS INDUSTRY IN INDIA:}

The industrial internal analysis can be done using many analytical methods which include, SWOC Analysis[16-17], BCG Matrix [18], ABCD Analysis [19-20], Six Thinking Hats [21-23], PEST analysis [24], Ideal system model-based analysis[25],Competitive forces analysis [26] Predictive analysis [27] etc. These analytical methods usually qualitative in nature, used to identify industry problems, status, or facts related to industry/organization /issue under consideration. The SWOC analysis reveals the internal status of the industry and in this study; we havestudied the strengths, weakness, opportunities, and challenges of agricultural organic products industry in India.Table 7 depicts the SWOC analysis of the agricultural organic products industry in India.

Table7: The SWOC analysis of the agricultural organic products in India

\begin{tabular}{|l|l|}
\hline Constructs & \multicolumn{1}{|c|}{ Features } \\
\hline Strengths on agricultural organic & $>\begin{array}{l}\text { Existence of appropriate regulation systems } \\
\text { produces in India }\end{array}$ \\
& $>\begin{array}{l}\text { Skill people involved in the production of agricultural } \\
\text { organic products }\end{array}$ \\
& $>$ Systematic certification for the agricultural organic products \\
\hline
\end{tabular}




\begin{tabular}{|c|c|}
\hline $\begin{array}{l}\text { Weakness on agricultural organic } \\
\text { produces in India }\end{array}$ & $\begin{array}{l}\text { There is no much marketing initiatives exist in Indian } \\
\text { economy for the agricultural organic products. } \\
\text { The prices of agricultural organic products are very high for } \\
\text { the Indian customers. } \\
\text { General awareness about the agricultural organic products is } \\
\text { very less among Indians. } \\
\text { To produce it in a larger number the financial support } \\
\text { provided for the production of agricultural organic products } \\
\text { are very less. } \\
>\text { Farmers who are producing agricultural organic products } \\
\text { are not much knowledge on technical aspects coz of lack of } \\
\text { skill which is necessary in the production of agricultural } \\
\text { organic products. }\end{array}$ \\
\hline $\begin{array}{l}\text { Opportunities for agricultural } \\
\text { organic produces in India }\end{array}$ & $\begin{array}{l}>\text { Creation of awareness about the agricultural organic } \\
\text { products. } \\
\text { Increase in the health consciousness and leading healthy } \\
\text { lifestyle has been increasing among the younger generation } \\
\text { where they concentrate more on organic products and create } \\
\text { high demand for it. } \\
>\text { Provision for the accurate information about agricultural } \\
\text { organic products. }\end{array}$ \\
\hline $\begin{array}{l}\text { Challenges for agricultural } \\
\text { organic produces in India }\end{array}$ & $\begin{array}{l}\text { Facing cutthroat competition from the worldwide. } \\
>\text { Creating knowledge among the people about agricultural } \\
\text { organic products. } \\
>\text { Need of muchmore initiatives from the government bodies } \\
\text { and HOPCOMS. } \\
\text { Majority of the people in India are not much concerned } \\
\text { about environmental issues in the country. }\end{array}$ \\
\hline
\end{tabular}

\section{FINDINGS OF THE STUDY :}

1. It is clear from the studies that the wild harvest area growth rate has been increased much higher than the cultivated area.

2. Consumers buying behaviour and health consciousness in developed economies are quite higher compared to developing economies.

3. The highest demand comes for Indian organic products are from the USA and Europe.

4. The study also has shown that organic agricultural areas used for the cultivation of organic agricultural products have been increased along with the increase in the product's level.

5. The study also reveals that countries like India have low health consciousness towards organic products where the sales are still in the introduction level.

6 . From the study, it is observed that some people do not buy organic agricultural products though they are health conscious due to the high price of organic products.

\section{FUTURE PREDICTIONS BASED ON PRESENT TREND :}

India being a developing country deals with the study of organic food products in comparison with other countries, where different countries deal with modern technology in comparison with past. But in the future the countries are more depended on sophisticated and very modern technologies which have good effect on the environment, people, the animals and bird species, but some of the technology process may have adverse effect on environmental pollution, natural resources and degradation of nature. To improve the present situation, it has become crucial for companies and business to plan for an ideal technology models which solves all the problems which particularly effect humans, the nature and environmental issues.The technology used should be a very simple and low cost which everyone can afford and used by all and everywhere existing. The best examples we 


\section{International Journal of Case Studies in Business, IT and Education SRINIVAS (IJCSBE), ISSN: 2581-6942, Vol. 2, No. 2, December 2018.

give are the cell phones and tablets which has easy access to the common man with regard to value and cost.

The developing and under developed countries have the major problems of food clothing and shelter and are suffering from lack of quality life and the gap between the haves and haves notare increasing. The main reasons for this disparity are the lack of social and technological development and ideal technology have the capability to solve these basic issues such as food, clothing, shelter, energy, and clean environment. In the future the ideal technology will play a crucial role in improving the standard of living of the people moreover the technology should be more convenient and towards the reach of people through low cost, simple, easy access, used by everyone and everywhere. As considered for an organic agriculture sector, it is more necessary to understand the technology or the clean technology, the green practices and impact of degradation of the environment, the pollution control devices, the renewable energy, the green manure, and the recycled products and the information of organic concepts.

One of the modern technologies called as Nano technology is expected to solve the various basic problem of food, clothing and shelter and also about the depleted resources, life span and green environment practices. The nanotechnology also solves the problem of agriculture food products and thereby improves the productivity of agriculture food and its demand.The Bio-diversity level has fallen and led towards destroys of forest where half of the forest has been destroyed. There is shortage of land area for cultivation due to industrialization. Throughnanosensors, pesticides and low-cost water purification method and pest control methods will help for good yield crops with low usage of water.

The nanotechnology also has a high impact on the portable drinking water both for agriculture sector and industries through innovative purification of water with low cost where there is a shortage of drinking water which is one of the earth`s main resources, where salt water can be easily used for drinking after it is processed through nanotechnology.The nanotechnology also has innovation based on usage of fabrics which help in improvement of these materials without an increase in weight, thickness or stiffness when compared to old techniques which benefit the fabrics without stain, wrinkle or bacteria.The other advent of nanotechnology is the research done on the human body. Since in the past human life span was very short but now in the present, it has increased significantly.The various life-threatening diseases which damage our body may be prevented by adopting a new method of nanorobots which repair our damaged cells and help to reduce the intensity of the diseases.

The company too can adopt the new modern technique of production which there by improves the productivity and employment opportunity of the population.The impact of usage of scarce resources and industrialization too may be harmful to the environment and damages the ozone layer of the earth, the nanotechnology provides solutions through nanosensors and also reduces the problems of inorganic methods of agriculture production.

\section{SUGGESTION AND RECOMMENDATIONS :}

(1) Since people in India are become more and more health conscious as well as started leading a healthy lifestyle the demand for organic products is increasing. So, in this regard, it is essential to create as much as possible the awareness among Indian who can be motivated to buy organic products. This can be done by giving importance to health consciousness aspect where consuming such organic products will help people to reduce fat contents in their body and leads to healthy digestion.

(2) From the secondary data, it is also clear that most of the western countries, as well as USA, are also exporting their organic farmed products in different parts of the globe. So, this is an eye opener for the Indians also to fetch a good price for their product by increasing the export of organic product worldwide and sustain with the existing cut-throat competition in the international market by improving the quality of the product. So, there is a need for export promotion zone and subsidies for the promotion of the export to other countries from India.

(3) There is a need for developing an action plan with regard to organic farming as well as the marketing of products. There is a need for evaluation and also for proper sequencing of the action 
which definitely boosts up the production capacity of the organic agricultural products and also exports of the products.

(4) It has become essential to make organic product related policies modifications, develop an appropriate programme and also plan for the development of organic farm from government bodies. Therefore, a strong national organic policy needs to be developed in order to bring overall development in the field of organic agriculture.

(5) Creation of awareness about the agricultural organic products, increase in the health consciousness and leading healthy lifestyle has been increasing among the younger generation where they need to concentrate more on organic products and create high demand for it. It is also essential to provide accurate information about agricultural organic products and also an appropriate assortment of organic products.

\section{CONCLUSION :}

Organic agriculture supports to sustain ecological system and cycles. It also enhances and sustains the health of soil, human, animals, plants, and planet. With regard to the growth of organic areas, the wild collection areas are higher when it is compared with the cultivated actual organic areas. The main organic products which have been produced in India are basmati rice, fruits, oilseeds, sugarcane, pulses, dry fruits, vegetables etc. Madhya Pradesh, Himachal Pradesh and Rajasthan in India are popularly known for the highest amount of production of organic products. Growing awareness towards environmental issues, health consciousness, leading a healthy lifestyle, is mainly responsible for the higher demand for organic agricultural products. People get safe and nutritious products by producing these organic products as well as by importing it from other nations. In urban areas heterogeneity cluster of people are more interested in buying organic label products in their daily life in western countries than India. Increase in the demand for these products in USA and Europe has helped developing nations to produce and export it in international level. The attractive market and high profit margin have motivated many farmers to venture into organic farming. The highest amount of organic basmati, organic spices, and organic herbs are produced by Indian farmers and started earning profits. Due to subdivision and fragmentation of landholding, ignorance, indebtedness, and disorganized market farmers in India are not able to fetch good prices for the products they produce. In India, there are 362exporters as well as 6.5 lakhs of producers who are involved in the export and production of organic agricultural products.

\section{REFERENCES :}

[1]Magnusson, M. Arvola, A, KoivistoHursti, U., Aberg, L., \&Sjoden, P. (2001). Attitudes towards organic foods among Swedish consumers. British Food Journal, 103(3), 209-227.

[2]Christos Fotopoulos, Athanasios Krystallis (2002). Purchasing motives and profile of the Greek organic consumer: a countrywide survey. British Food Journal, 104(9), 730-765. DOI: https://doi.org/10.1108/00070700210443110.

[3] Anne Davies, Albert J. Titterington, Clive Cochrane (1995). Who buys organic food? A profile of the purchasers of organic food in Northern Ireland.British Food Journal, 97(10), 17-23. DOI: https://doi.org/10.1108/00070709510104303.

[4]Marija Radman (2005).Consumer consumption and perception of organic products in $\begin{array}{llll}\text { Croatia.British Food Journal, } & \text { 107(4), }\end{array}$ DOI:https://doi.org/10.1108/00070700510589530.

[5]Giuseppe Pellegrini, Federica Farinello (2009).Organic consumers and new lifestyles: An Italian country survey on consumption patterns. British Food Journal, 111(9), 948974. DOI: https://doi.org/10.1108/00070700910992862.

[6] Maria L. Loureiro, Jill J. McCluskey, and Ron C. Mittelhammer (2001). Assessing Consumer Preferences for Organic, Eco-labeled and Regular Apples. Journal of Agricultural and Resource Economics, 26(2), 404-416. 
[7]Nizar, S.\& Mariam D. (2009). Canadian and French men's consumption of cosmetics: A comparison of their attitudes and motivations.Journal of Consumer Marketing, 26(2), 97-109.

[8]Richardson, N. (2004). Getting inside men's health. Health Promotion Department, South Eastern Health Board, Kildare,1445.

[9]Aoun, S. Donovan, R.J. Johnson, L.\& Egger, G. (2002). Preventive care in the context of men's health.Journal of Health Psychology, 7(3), 243-252.

[10]Tregear, A. Dent, J.B. McGregor, M.J. (1994). The demand for organically grown produce.British Food Journal, 96(4), 21-25.

[11]Schifferstein, H.N.J., \&Oude Ophuis, P.A.M. (1998). Health-related determinants of organic food consumption in the Netherlands. Food quality and preference, 9 (3), 119-133.

[12] Krystallis, A. Vassalo, M. Chryssohoidis, G. \&Perrea, T. (2008). To buy or not to buy organic food Societal and individualistic drivers as predictors of organic purchasing revealed through a Portrait Value Questionnaire (PVQ)-based inventory.Journal of Consumer Behaviour, 7(2), 164187.

[13] Gaetano Chinnici, Biagio Pecorino and D’Amico Mario (2002). A Multivariate Statistical Analysis on the Consumers of Organic Products. British Food Journal, 104(3), 187-199.

[14]Gemma C. Harper, Aikaterini Makatouni (2002) Consumer perception of organic food production and farm animal welfare. British Food Journal, 104(4), 287-299. DOI: https://doi.org/10.1108/00070700210425723.

[15]O’Donovan, P. \&McCarthy, M. (2002). Irish consumer preference for organic meat. British Food Journal, 104(5), 353-370. DOI: https://doi.org/10.1108/00070700210425778.

[16]Humphrey, A. S. (2005). SWOT analysis. Long Range Planning, 30, 46-52.

[17] Aithal, P. S. \& Suresh Kumar, P. M. (2015). Applying SWOC Analysis to an Institution of Higher Education. International Journal of Management, IT and Engineering (IJMIE), 5(7), 231-247, DOI: http://doi.org/10.5281/zenodo.163425.

[18] Henderson, B. D. (1979). The product portfolio: growth share matrix of the Boston ConsultingGroup. The strategy process: Concepts, contexts, cases, 678-680.

[19]Aithal, P. S. (2016). Study on ABCD Analysis Technique for Business Models, business strategies, Operating Concepts \& Business Systems, International Journal in Management and Social Science, 4(1), 98-115. DOI:http://doi.org/10.5281/zenodo.161137.

[20]Aithal, P. S., Shailashree, V.T., \& Suresh Kumar, P.M. (2015). A New ABCD Technique to Analyze Business Models \& Concepts.International Journal of Management, IT and Engineering (IJMIE), 5(4), 409 - 423. DOI:http://doi.org/10.5281/zenodo.61652.

[21]De Bono, E. (1999) Six Thinking Hats, Back Bay Books, New York.

[22]Aithal, P. S. \& Suresh Kumar, P. M. (2017). Lateral Thinking in Managerial Decision Making Through Six Thinking Hats Technique. International Journal of Scientific Research and Modern Education (IJSRME), 2(1), 53-58. DOI: http://dx.doi.org/10.5281/zenodo.438149.

[23] Aithal, P. S. \& Suresh Kumar, P. M. (2017). Ideal Analysis for Decision Making in Critical Situations through Six Thinking Hats Method. International Journal of Applied Engineering and Management Letters (IJAEML), 1(2), 1-9. DOI: http://dx.doi.org/10.5281/zenodo.838378.

[24]Gupta, A. (2013). Environment \& PEST analysis: an approach to external businessenvironment. International Journal of Modern Social Sciences, 2(1), 34-43.

[25]Aithal, P. S. (2016). Review on Various Ideal System Models Used to Improve the Characteristics of Practical Systems. International Journal of Applied and Advanced Scientific Research, 1(1), 47-56. DOI:http://doi.org/10.5281/zenodo.159749. 
[26] McMillan, C. (2010). Five competitive forces of effective leadership and innovation. Journal of Business Strategy, 31(1), 11-22.

[27]Shubhrajyotsna Aithal \& Aithal, P. S. (2018). The Realization Opportunity of Ideal Energy System using Nanotechnology Based Research and Innovations. International Journal of Advanced Trends in Engineering and Technology, 3(2), 1-15. 